\author{
Jolanta Latosińska \\ Dorota Ludwicka \\ Łódź University \\ Institut of Urban Geography and Tourism \\ e-mail: jlatos@geo.uni.lodz.pl; ludwicka.dorota@gmail.com
}

\title{
TOURISM ACTIVITY AMONG UNIVERSITY STUDENTS: A SURVEY FROM UNIVERSITIES IN ŁÓDŹ
}

\begin{abstract}
The article presents conclusions on the tourism activity of university students in Łódź. It is based on a survey conducted in October and November 2008 among final year students at six state-run universities in Łódź. The article presents the socio-demographic structure of the respondents, their tourism trips and the factors influencing them, while the conclusions offer a functional model of recreation for the groups investigated.
\end{abstract}

Key words: tourism activity, students, active tourism, specialised tourism, free time, individual tourism space, Łódź.

\section{INTRODUCTION}

As young people entering adult life, students have a relatively large amount of free time. When they are not busy studying, they use their free time to rest or work. It can be assumed that, similar to all university students, students at Łódź universities are young and fit, need to spend their time actively and prefer active forms of tourism, and specialised tourism in particular.

As the key words used in this article are widely defined in the literature (WARSZYŃSKA \& JACKOWSKI, 1979, DZIEGIEĆ \& BACHVAROV, 2005, ŁOBOŻEWICZ \& BIEŃCZYK, 2001), the authors decided not to include a review of publications on this terminology. However, because of the research methodology, it should be stressed that the object of study was the tourism activity of university students during the long summer and long winter holidays, public holidays and weekends. The study excluded trips made for strictly earning purposes, but they included tourism trips made while working abroad on days free from work (e.g. as part of the Work and Travel programme). Weekend trips are considered as being made during the academic year (so excluding the breaks between semesters), but including the so-called 'long weekends' at festivals (so not necessarily only on Saturdays and Sundays, as such trips are often extended by 2-3 days). All trips referred to as 'public holiday trips' take place for instance at Easter, during the long May weekend (around May 1 $1^{\text {st }} \& 3^{\text {rd }}$ ), around Corpus Christi, Christmas, New Year and on other occasions.
Those in the long summer and winter holidays are generally referred to as 'vacation trips'.

The survey was carried out in October-November 2008 among students of the University of Łódź, the Technical University of Łódź, the Medical University, the Academy of Fine Arts, the Musical Academy and the State Higher School of Film, Television and Theatre. Final year students only were selected (on the fifth year of full time study ${ }^{1}$, or the second year of a Master's degree) and concerned tourism trips made by those students from 2004 to 2008 .

There were 200 respondents in the survey from 8109 possible students $(2.5 \%$ of the total population at state-run universities) who met the criteria: 107 (53\%) from the University of Łódź, 57 (28\%) from the Technical University, 23 (11\%) from the Medical University, as well as $13(8 \%)$ from the remaining three universities (5 from the Academy of Fine Arts, 5 from the Musical Academy and 3 from the State Higher School of Film, Television and Theatre).

A quota sample was chosen and the number of questionnaires was proportional to the overall number of students at each of the universities. The questions concerned the duration of the trips, their frequency, organization, spatial range, determining factors, etc. Personal details included sex, year and place of birth, current place of residence, field of study, department and university (with an option to record the study of two subjects), paid work, earned income and grants, parent's education and the financial situation at home. 
This article presents only a part of the material collected in the survey.

In this way the authors collected data on 1393 tourism trips (708 during long holidays, 444 at weekends and 241 during public holidays).

\section{SAMPLE DESCRIPTION}

The survey included 118 women (59\%) and 82 men $(41 \%)$. A vast majority of the respondents were aged $23(76 \%), 27$ were one year older and four one year younger, nine were 25 , three -26 , two -28 and one 29. Among those over 23 were students from the Medical University, where courses last six years (four students), as well as students from the other universities.

The respondents came mainly from central Poland: the majority from Łódź Wojezództwo (149, i.e. about. $75 \%)$ and neighbouring Województwos.

It was discovered that a relatively large number were not financially dependent on their parents, or earned additional money for their expenses (40\% of the respondents worked). Only $31 \%$ had no intention of working, were without a job or seeking employment. Average monthly income, as stated and including grants, was below 500 zlotys, but 45\% claimed more than 500 zlotys and half of those as exceeding 1000 zlotys. Only 18\% of the respondents claimed they did not have any income. Asked about the financial situation at home, the respondents usually described it as good $(51 \%)$, average $(36 \%)$, or very good $(10 \%)$, while $3 \%$ admitted that it was bad.

The study shows that students mostly have their own income, so we may assume that some of it may be spent on tourism trips. In their last year students have completed sufficient study to start work but simultaneously plenty of free time, due to fewer classes. Moreover, as students they are willingly offered jobs by employers who gain tax relief in this way.

\section{THE TOURISM BEHAVIOUR OF THE RESPONDENTS IN TEMPORAL, SPATIAL AND FUNCTIONAL TERMS}

The free time that remains after university work, as well as after duties at home and work, is an opportunity for all kinds of tourism trip both short- and long term. At most Polish universities the academic year consists of two 15-week long semesters. Between the beginning of the academic year of 2004/5 to the start of the survey (1 $1^{\text {st }}$ October 2008), the number of days free of study was calculated at $774^{2}$. The average number of free days per academic year during that period was 193.25. The largest number were accounted for by the long summer and winter holidays (409 days), 53\% of the total. A vast majority of students used some of that time for tourism trips: $85.5 \%$ reported at least one trip over the long summer and winter holidays. The number of free days during weekends, understood as the total of Saturdays and Sundays (excluding public holidays) was 312, while there were 53 days of 'public holiday'.

The data collected in the survey concerned 1393 tourism trips. Only 17 respondents (8.5\%) said they had not undertaken any tourism trips while at university. The graph presents the seasonality of tourism trips in the sample group (Fig. 1) and shows that August is the peak followed closely by July. The next peak is observed in May when the students have a 'long-weekend' and the weather encourages them to go on trips. The figure in June was lower, because despite being the beginning of summer, students are unable to go as they are preoccupied with the summer exam session. September, which is formally a holiday month, is the time of exam re-sits for some students, therefore the figure is similar to June. In the autumn months figures decrease from September to November, along with the temperature. In December there is another increase, related to the Christmas break which lasts until the beginning of January. Next, in February there is a decrease, but only slight as some students leave during the long winter holiday. The lowest figures are for November and March, due to adverse weather conditions.

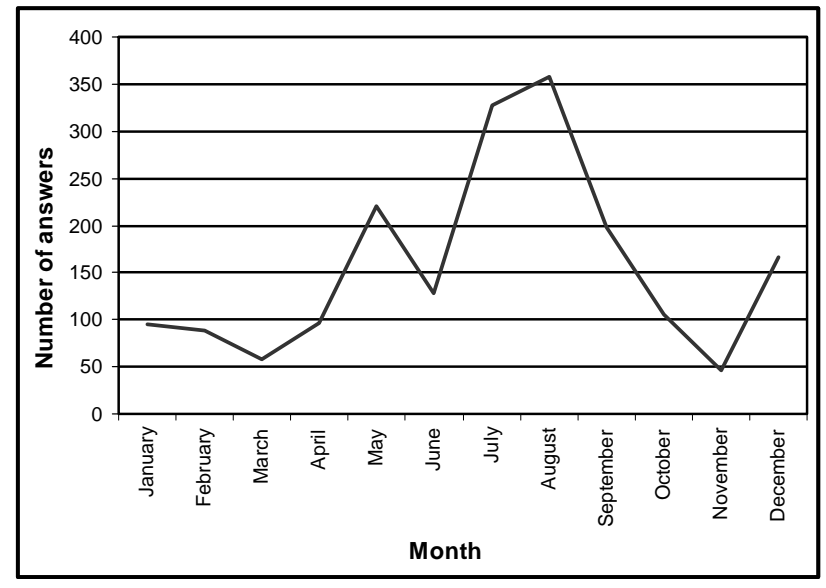

Fig. 1. Seasonality of tourism trips: long holidays, public holidays, weekends (s o u r c e: author based on questionnaire)

As regards the duration of tourism trips, most did not exceed two weeks (Fig. 2). Weekend trips obviously lasted 1-2 days, and 'public holiday' trips 
about 4-7 days. The longest were during the summer and winter holiday seasons; usually lasting one or two weeks (which to a certain extent could depend on trips organised for fixed periods). In some cases they lasted 3 or 4 weeks, and sometimes even longer than a month. The arithmetical mean for duration was 8.14 days, while the average duration during summer and winter holidays was 12.26 days.

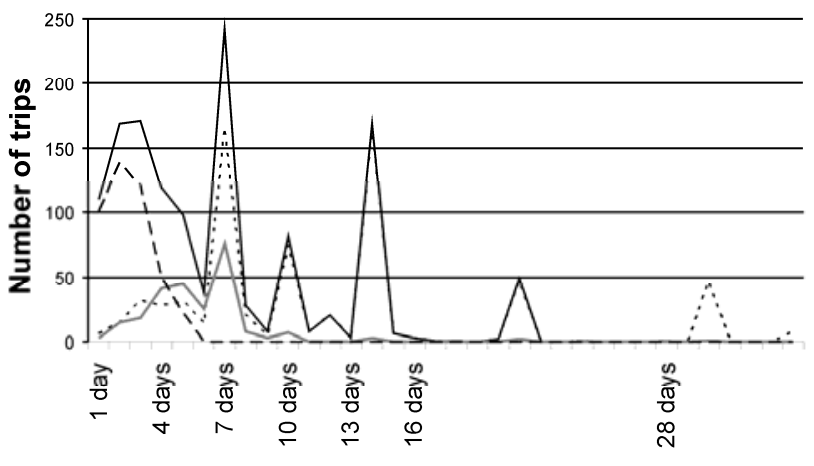

Duration of trip

\begin{tabular}{|c|c|}
\hline - & Total \\
\hline ...... & $\begin{array}{l}\text { Trips during summer } \\
\text { and winter holidays }\end{array}$ \\
\hline & $\begin{array}{l}\text { Trips during public holidays } \\
\text { Trips during weekends }\end{array}$ \\
\hline
\end{tabular}

Fig. 2. Duration of long holiday, public holiday and weekend trips (s o u r c e: author based on questionnaire)
The respondents made 444 weekend tourism trips, although 77 from the 200 stated that they had never made one. During public holidays, tourism trips were not very popular with a total of 241, while half took no trip during public holidays over their whole period at university. It must be noted, however, that free time on public holidays constitutes only $7 \%$ of all days free of study. The summer and winter long holidays occupy $53 \%$ of students' free time; therefore it was then that the majority were made (708). Only 26 from the 200 took no tourism trips during summer and winter long holidays.

The respondents' physical activity index during tourism trips was the percentage during which active tourism was undertaken, $78 \%$ over the studied period.

An analysis of the destinations chosen by the respondents (creating individual tourism space), showed that most trips took place in Poland $(63 \%$, $21.7 \%$ of which were in Łódź). Out of all the trips, 31\% were made to other European countries, while $6 \%$ were to destinations outside Europe. In this article the author presents the Polish destinations of tourism trips within the tourism regions of the country, as established by KRUCZEK \& SACHA (1977). The thematic map below (Fig. 3) presents the Polish destinations

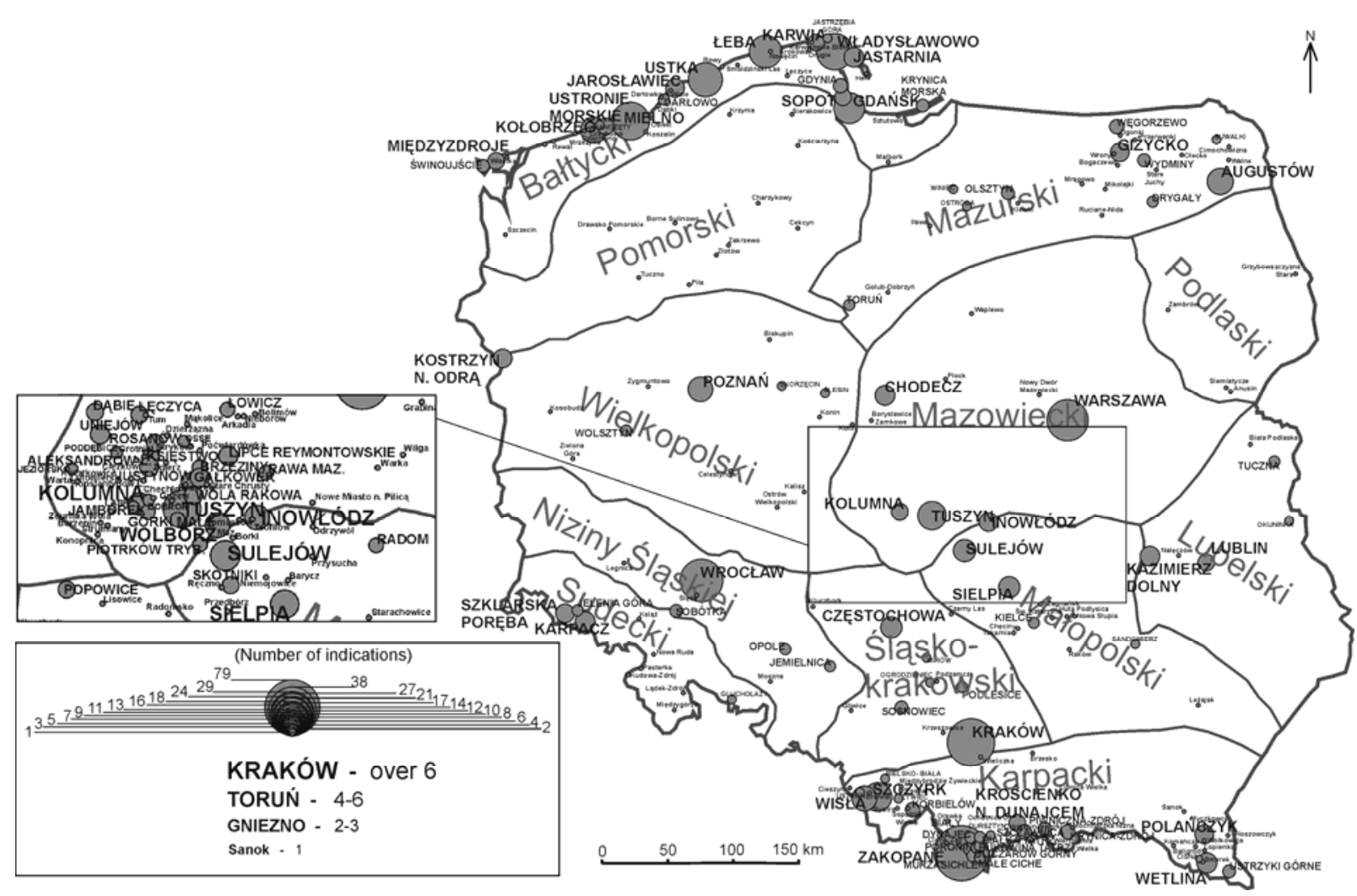

Fig. 3. The main tourist destinations in the tourist regions of Poland, chosen by the students of Łódź state universities in $2004-2008$ (division into regions: KRUCZEK, SACHA 1994). Number of indications: over 6 indications, 4-6 indications, 2-3 indications, 1 indication (s o u r c e: author's compilation based on survey) 


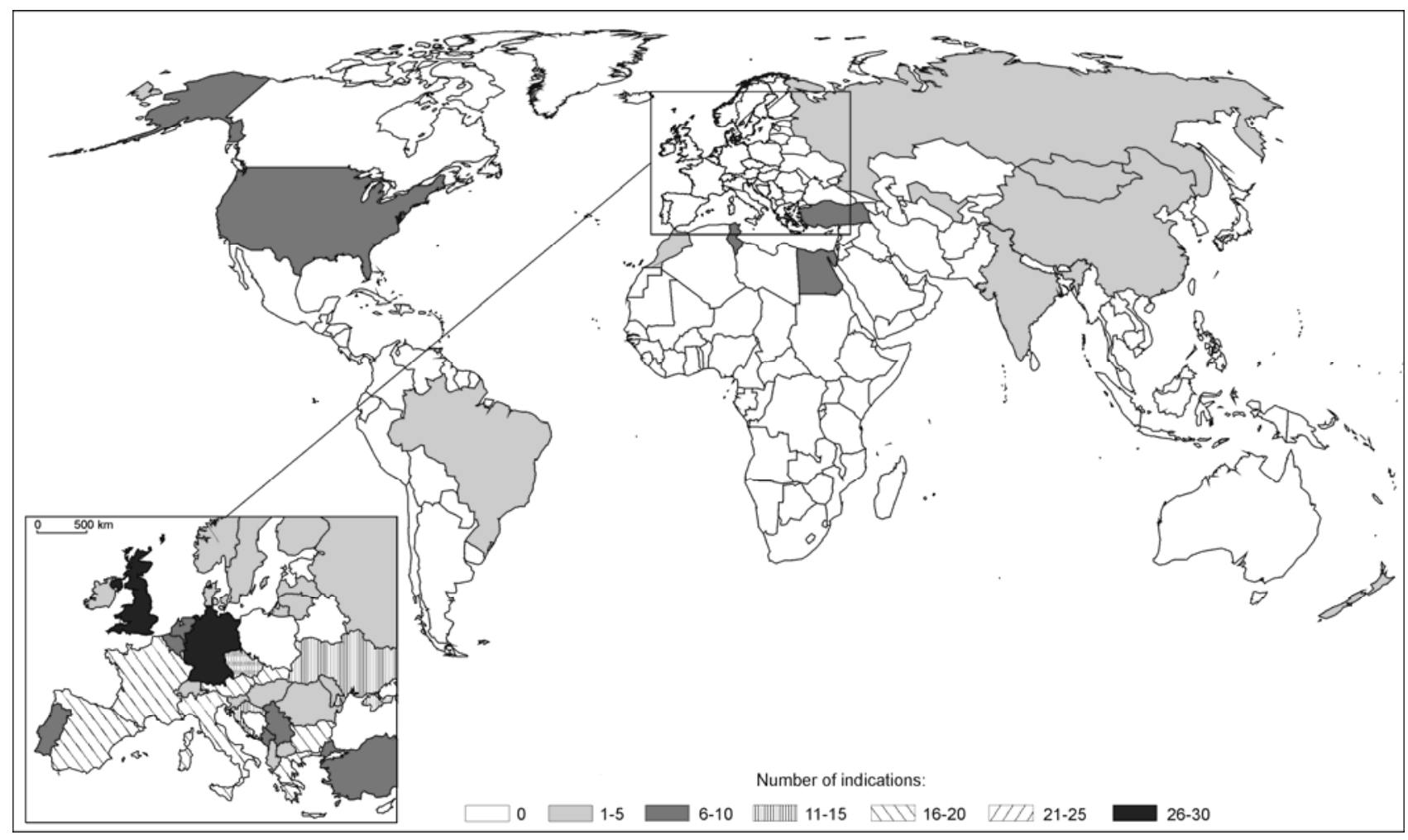

Fig. 4. Major foreign tourist destinations, chosen by the students of Łódź state universities in 2004-2008 (source: author's compilation based on survey)

of tourism trips: mainly to the Baltic region, the Carpathian region, in the Pieniny Mountains and in the Beskid Sądecki region. Due to the close distance from Łódź, the destinations were often in the Mazowsze region, above all in towns and villages near Łódź. Other regions which are relatively popular were the Mazury region and the Kraków-Częstochowa Jurassic Uplands. Destinations frequently visited included the Sudety Mountains and Lublin Uplands. Many students visited large cities, such as Kraków, Wrocław, Warsaw, Poznań and Gdańsk. All the trips to Kostrzyn on the Odra River were related to the 'Woodstock' festival, an event popular among young people.

As regards foreign tourism, the most popular destinations were Great Britain (31) and Germany (30). A lot of those trips were for sightseeing. All the countries visited are presented on the map of the world (Fig. 4) and show that, apart from Great Britain and Germany, students most frequently visited Italy (20), France (19), Austria (18), Bulgaria (18), Slovakia (18), Greece (16), Spain (16), Croatia (14), Ukraine (12), the Czech Republic (11), Egypt (10), Tunisia (10), the USA (10), the Netherlands (9), Serbia (9), Montenegro (8), Belgium (7), Portugal (7) as well as other countries.

In comparison with the data provided by the Institute of Tourism on foreign trips made by Poles, students mostly preferred Great Britain, but also chose other countries such as Bulgaria, Greece, Croatia or Spain, i.e. tourism destinations which have recently become a little less trendy than several years ago, but are affordable for students. Other countries, which were visited by students more frequently included the USA, Tunisia, France, Egypt, Ukraine, Austria and Turkey. Despite the large number of trips to Germany, they were less popular among students than among Poles generally. Countries which were visited less often than average included the Czech Republic, Lithuania, Sweden, Hungary and Norway. The figures on trips to Slovakia, Italy and Belgium were closest to those quoted by the Institute of Tourism (www.intur.com.pl).

In order to compare the recreation opportunities of students at individual universities and establish to what extent they satisfied their needs in this respect, functional models of recreation for the students of each university were created. The results are presented on a diagram (Fig. 5), based on the components included in Table 1: a holiday activity index (calculated as the ratio of the percentage of those staying away from place of residence for longer than seven days, to the size of the sample group); the percentage who went on such a trip at least once a year over the studied period; the amount of free time used for recreation purposes 
(based on the ratio of the number of days spent on tourism activities, away from place of residence, to the total number of days free of study over the whole period of their studies); as well physical activity during tourism trips (defined as the percentage of trips involving active tourism). In this model, the level of needs satisfaction increases together with the values of all the factors mentioned, measured on a four-point scale (unsatisfactory, satisfactory, good and very good), changing every 25 units (LATOSIŃSKA, 1998). On the basis of the diagram of recreation models among the students of individual universities in Łódź (Fig. 5), it can be concluded that over the studied period the sample group satisfied their needs for

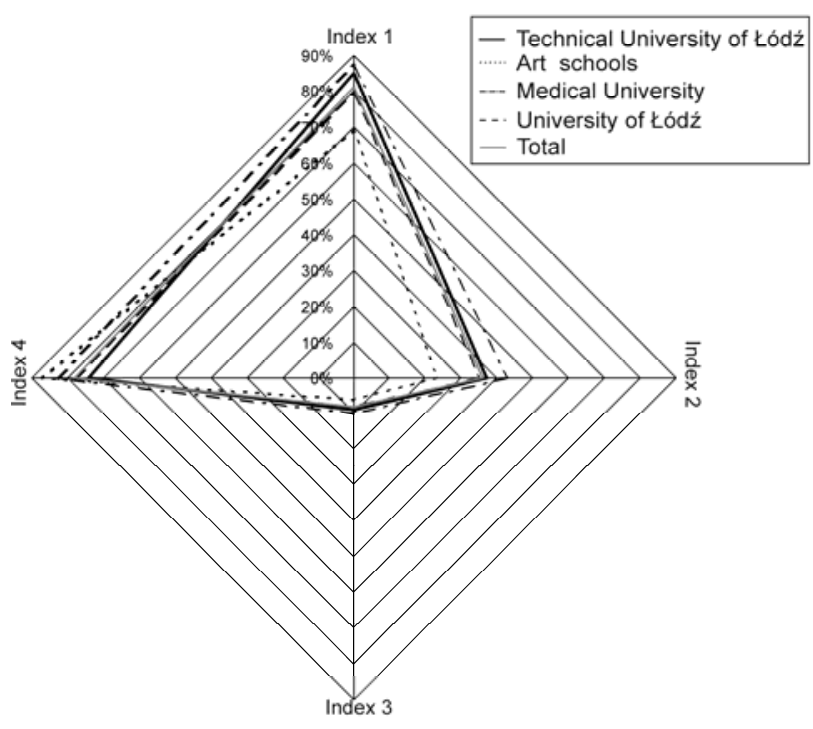

Fig. 5. Functional model of recreation of the students at Łódź state universities in 2004-2008

1 - holiday activity index; 2 - percentage of persons who went on annual holiday for at least 7 days, 3 - the amount of free time used for tourist purposes; 4 - physical activity index during the holiday

(s o u r c e: author's compilation based on survey) recreation, physical activity and use of free time for tourism purposes in 51.7\% (Table 1). On the four-point scale used by the author, this value falls between $50 \%$ and $75 \%$ which means a good degree of need satisfaction. However, considering each university individually, the students of arts-based universities satisfied their needs only to a satisfactory degree (46.2\%). The respondents from the Medical University displayed the highest average value, while the students of the Technical University and University of Łódź had slightly worse results. The diagram shows that the sub-group which is most similar to the figure for the whole are students of the University of Eódź, as the values calculated for this particular group are almost identical to those calculated for all the respondents. It must be remembered, however, that the majority of questionnaires were distributed at this particular university. The diagram also shows that the students of Medical University used their free time for tourism purposes the most.

The author assumed that the students felt a strong need to spend their free time actively, therefore a very important component of the model was the respondents' physical activity during tourism trips. The values here were high for each of the universities (78\% on average), thus this hypothesis was proved. The students who were most interested in physical activity during tourism trips were those from the artsbased universities and the Medical University. Slightly less interested were respondents from the University of Łódź, and the least interested - the students of the Technical University of Łódź. This result came as a surprise, because the latter boasts many organizations offering active forms of tourism to students.

The information concerning holiday, weekend and public holiday trips was used to create a similar diagram (Fig. 6). In this case, however, the author was unable to use the first two components included in the previous one, as short weekend trips were also considered.

$\mathrm{T}$ a b l e 1. Indices used for the construction of a functional model of recreation among the students of state-run universities in Łódź, including long holiday, public holiday and weekend trips

\begin{tabular}{|c|c|c|c|c|c|}
\hline & $\begin{array}{c}\text { University } \\
\text { of Łódź }\end{array}$ & $\begin{array}{c}\text { Technical } \\
\text { University } \\
\text { of Łódź }\end{array}$ & $\begin{array}{c}\text { Medical } \\
\text { University }\end{array}$ & $\begin{array}{l}\text { Arts-based } \\
\text { universities }\end{array}$ & Total \\
\hline Holiday activity index (\%) & 79.0 & 85.0 & 87.0 & 69.0 & 81.0 \\
\hline Percentage who made an annual trip lasting at least 7 days & 35.0 & 37.0 & 43.0 & 23.0 & 36.0 \\
\hline Use of free time for tourism purposes (\%) & 8.0 & 9.0 & 10.0 & 6.0 & 8.0 \\
\hline Physical activity index during trips (\%) & 78.0 & 74.0 & 83.0 & 87.0 & 78.0 \\
\hline Average (\%) & 50.0 & 51.2 & 56.7 & 46.2 & 51.7 \\
\hline
\end{tabular}

S o u r c e: Author based on questionnaire. 
$\mathrm{T}$ a b l e 2. Indices used for the construction of the functional model of recreation among the students of state-run universities in Łódź, including long holiday, public holiday and weekend trips

\begin{tabular}{|c|c|c|c|c|}
\hline & $\begin{array}{l}\text { Holiday } \\
\text { tourism }\end{array}$ & $\begin{array}{l}\text { Weekend } \\
\text { tourism }\end{array}$ & $\begin{array}{c}\text { Public holiday } \\
\text { tourism }\end{array}$ & Average \\
\hline Tourism activity index (\%) & 87.0 & 61.0 & 50.0 & 66.0 \\
\hline Percentage of persons who went on a trip every year & 33.5 & 21.0 & 5.5 & 20.0 \\
\hline Physical activity index during trips (\%) & 70.4 & 82.0 & 86.0 & 79.5 \\
\hline Average (\%) & 63.6 & 54.7 & 47.2 & 55.2 \\
\hline
\end{tabular}

Sou r c e: Author based on questionnaire.

In this case the author used the tourism activity index, which expresses the percentage of those who went on a tourism trip (holiday, weekend, public holiday) during the studied period. The most popular were the long holiday trips, followed by weekend and public holiday trips. The second component of the diagram was the percentage who went on a trip regularly every year, over the whole studied period (Table 2). The most frequent were long holiday trips, followed by weekend and finally public holiday trips. The third component was the degree of physical activity during the trips (defined on the basis of the percentage of trips with active forms of tourism). In this way, the diagram showed functional models of holiday, weekend and public holiday recreation among the respondents (Fig. 6).

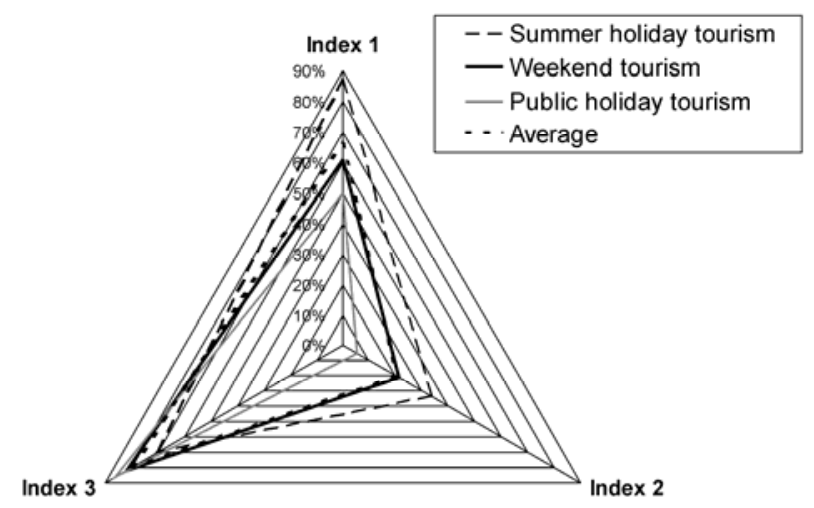

Fig. 6. Functional model of weekend, public holiday and summer holiday recreation of the students at Łódź state universities in $2004-2008$

1 - tourist activity index; 2 - percentage of persons who went on a given type of holiday every year; 3 - physical activity index during the holiday

(s o u r c e: author's compilation based on survey)

The recreation model diagram allows us to conclude that the sample group satisfied their need for recreational physical activity to a good degree by going on trips during summer and winter long holiday, and to a satisfactory degree by going on public holiday trips.
The study shows that the majority of students plan to spend the coming holidays abroad $(40 \%)$, about a third of the respondents still do not know how they will spend the summer, a quarter of them plan to travel somewhere in Poland, and 7\% claim that they most probably will not go anywhere. As far as the respondents' dreams are concerned, over $95 \%$ of them dream of travelling to European countries and to other continents (above all to South America and Asia, then to Australia, North America, Africa and Latin America). As for European countries, most people mentioned Spain, Italy, France, Greece, Croatia and other countries as their dream destinations. As regards countries outside Europe, most chose the USA, Egypt, China and Japan, followed by India, New Zealand and Mexico.

The kind of tourism popular with students, frequency of trips and the choice of destinations are influenced by a variety of factors. The most important are demographic and cultural factors (age, parents' education, habits), socio-vocational (childhood and early youth experiences, vocational status, being a student of a given university, specialization), economic (students' and their families' financial situation), geographical (place of birth, residence) factors, as well as the long tradition of university tourism and travelling to work.

\section{CONCLUSIONS}

The assumption made by the author has been confirmed because when asked about their preferred type of tourism, $67.5 \%$ of the respondents chose active tourism, involving physical activity, only $25 \%$ preferred moderately active tourism (e.g. going to the beach), and $7.5 \%$ did not have any opinion. In practice, the respondents were even more active - the analysis of 1393 trips made by the students over the whole period of studies shows that $78 \%$ of them were spent actively, assuming that tourism was combined with 
certain forms of active recreation. The survey confirms that students often undertake specialised tourism (walking, water, cycling, winter sports) and go to sports holiday camps. In nearly one third of the tourism trips the students chose passive recreation, e.g. lying on a beach. The weekend and public holiday trips were spent more actively than long summer and winter holidays because during weekends the students very often used their bikes as a means of transport $30 \%$. In $17 \%$ the students went walking, which was followed by winter sports (6\% of trips), cycling (3\%), sailing and different kinds of sports camps. Long holiday trips were less active, but the students often did water sports, such as canoeing, sailing or diving. The forms of tourism typical of weekends included horse-riding and cycling. Sightseeing tourism was frequently combined with walking and cycling, and much more rarely with spending time passively. Only $17 \%$ of the students declared that they had taken no tourism trips over their four years of studies. As for the students' dreams, they were difficult to fulfil and regarded mainly remote, exotic places, which the students had not had a chance to visit yet.

\section{FOOTNOTES}

${ }^{1}$ In the case of the Medical University, the authors selected sixth year students.

${ }^{2}$ The number of days free of study in the studied period was calculated on the basis of archival calendars containing lists of 'Rector's' days and published officially on university websites.

\section{BIBLIOGRAPHY}

DZIEGIEĆ E., BACHVAROV M., 2005, Relacje między pojęciami „rekreacja" i "turystyka", Turyzm, 2005, t. 15, z. 1, s. 79-93.

JAŻDŻEWSKA I., 2003, Statystyka dla geografów, Wydawnictwo Uniwersytetu Łódzkiego, Łódź.

KRUCZEK Z., SACHA S., 1994, Geografia atrakcji turystycznych Polski, Oficyna Wydawnicza Ostoja, Kraków.

LATOSIŃSKA J., 1998, Przestrzeń urlopowo-wakacyjna pracowników wyższych uczelni Łodzi, Łódzkie Towarzystwo Naukowe, Łódź.

ŁOBOŻEWICZ T., BIEŃCZYK G., 2001, Podstawy turystyki, Wydawnictwo Wyższej Szkoły Ekonomicznej, Warszawa.

WARSZYŃSKA J., JACKOWSKI A., 1979, Podstawy geografii turyzmu, PWN, Warszawa.

www.intur.com.pl [02.07.2009]. 